\title{
Cellulose nanocrystals induce a dose-dependent effect on cytotoxicity and proliferative activity of human peripheral blood mononuclear cells
}

\section{Miloš Vasiljević', Sergej Tomić Marina Bekić ${ }^{2}$ Bojan Joksimović', Dragana Vučevićs, Miodrag Čolići,2}

'University of East Sarajevo, Faculty of Medicine Foca, Center for Biomedical Sciences, Foca, The Republic of Srpska, Bosnia and Herzegovina

${ }^{2}$ University of Belgrade, Institute for Application of Nuclear Energy, Belgrade, Serbia

${ }^{3}$ Military Medical Academy, Institute for Medical Research, Belgrade, Serbia

Primljen - Received: 11/01/2020

Prihvaćen - Accepted: 29/05/2020

Corresponding author:

Teaching assist. Miloš Vasiljević

Studentska 5, 73000 Foca, Republika Srpska vasiljevicmilos85@gmail.com

Copyright: @2020 Vasiljević M, et al. This is an Open Access article distributed under the terms of the Creative Commons Attribution 4.0 International (CC BY 4.0) license.

\begin{abstract}
Summary
Introduction. Cellulose nanocrystals (CNCs) as attractive natural materials, have numerous applications in the biomedical field. Their unique biomechanical characteristics, surface chemistry, low cost and sustainable nature make them an engaging alternative to conventional materials and potentiate their use as progressive material. Therefore, it is critical to evaluate the cytocompatibility and immunomodulatory properties of $\mathrm{nCNCs}$, which have not been completely explored. The objective of this study was to examine a dose-dependent effect of native (n)CNCs on cytotoxicity and proliferative activity of human peripheral blood mononuclear cells (PBMNCs) in vitro.
\end{abstract}

Methods. PBMNCs, obtained from the healthy blood donors, were cultivated with nCNCs. Cell viability was analyzed by flow cytometry assay, while proliferative activity was determined by MTT, [3H]-thymidine uptake assay and detection of IL-2 production.

Results. The cytotoxicity results suggested that no concentration of $\mathrm{nCNCs}$ $(50-400 \mu \mathrm{g} / \mathrm{ml})$ affected necrosis of PBMNCs, whereas apoptosis was induced by the highest concentration of $n C N C s$ compared to control $(p<0.05)$. Unexpectedly, the highest concentration of $\mathrm{nCNC}$ increased the metabolic activity of PHA-stimulated cells compared to control $(p<0.05)$. In contrast to these findings, lower concentrations of nCNCs $(50 \mu \mathrm{g} / \mathrm{ml}$ and $100 \mu \mathrm{g} / \mathrm{ml})$ stimulated proliferation of PBMNCs $(p<0.05$ and $p<0.001)$. It was followed by increased production of IL-2 $(100 \mu \mathrm{g} / \mathrm{ml})(p<0.001)$.

Conclusion. The results suggest that non-cytotoxic concentrations of nCNCs modulate the proliferative activity of human PBMNCs, a phenomenon which has not been published up to now and which is relevant for further studies.

Keywords: cellulose nanocrystals, peripheral blood mononuclear cells, culture, cytotoxicity, proliferative activity

\section{Introduction}

In recent years, natural polymers, especially cellulose, present popular area of intense research in biomedicine [1]. Nanoscaled form of cellulose, (nanocellulose) attracts more attention as unique and sophisticated material. Unlike traditional materials, nanocellulose is characterized by biocompatibility, non-toxicity, biodegradability, combined with outstanding mechanical and chemical properties, low cost, availability, and sustainability [2]. Such qualities offer numerous application opportunities 
of nanocellulose in various technical, nutritional, pharmaceutical and biomedical areas [3, 4].

Depending on the source and the chemical treatment, nanocellulose can be classified into three major types: cellulose nanofibrils (CNFs), cellulose nanocrystals (CNCs) and bacterial cellulose (BC). Takng into accound that cytotoxicity is a crucial parameter of biocompatibility, CNFs can be recognized as safe and biocompatible material, as pointed out by several papers [5-7]. In vitro reports concerning the CNF immunomodulatory abilities in two models of human immune cells, Čolić et al. confirmed tolerogenic capacity of CNFs $[8,9]$. This was estimated by means of the inhibitory effect of CNFs on T helper1 (Th1), Th17 responses and T-cell activation, as well as by expanding Th2 cells, activating regulatory $\mathrm{T}$ cells (Tregs) and increasing the production of immunoregulatory cytokines. The latter study showed that phosphonation of CNFs enhanced these properties [10].

Cellulose chains parallely packed into filamentous structures formed needle-like CNCs (high-aspect-ratio nanoparticles, HARN $\geq 3$ ). Due to the uniaxial orientation of these chains and the high degree of crystallinity, CNCs possesed tremendous stiffness and strength [11]. Having these characteristics, cellulose nanocrystals have obtained increasing attention recently as a result of the renewable nature of the source, comparatively low cost, low density, as well as its biodegradability. Other attractive features are the ability of CNCs to interact with other polymeric matrix materials and possibility of chemical modifications due to the abundance of surface hydroxyl groups [12]. All these features make CNCs attractive for a wide spectrum of new applications.

Taking into account that nanocellulose, including $\mathrm{CNCs}$, has had commercial applications, controversy concerning its biocompatibility and immunomodulatory properties has been actualized. As it has been already mentioned, cellulose is generally considered to be biocompatible and safe material $[2,13,14]$. In contrast, cytotoxic and inflammatory effect of CNCs was confirmed in vivo, using a mice model [15]. Namely, pulmonary exposition to two types of CNCs such as powdered $\mathrm{CNC}(\mathrm{CNCP})$ and $\mathrm{CNC}$ suspension (CNCS) induced increased production of pro-inflammatory cytokines, particularly tumor necrosis factor (TNF)- $\alpha$ and interleukin (IL)-1a and activation of Th1 (CNCS) and Th2 (CNCP) immune responses. These results were in accordance with the results of Clift et al., who showed slight cytotoxic and inflammatory effect of $\mathrm{CNCs}$ in a model of human epithelial triple-cell co-culture [16]. However, such a phenomenon was not demonstrated against nine different cell lines, although applied concentrations of CNCs were similar [17]. In a realistic and efficient 3D model of the human epithelial tissue cells, Endes and co-workers tested aerosolised CNCs at a concentration of 0.14 to $1.57 \mu \mathrm{g} / \mathrm{cm}^{2}$. After 24 -hour post-exposure they did not identify cytotoxicity, oxidative stress and (pro-)inflammatory response considering the production of IL- 8 and TNF- $\alpha$ [18]. In line with these results, Catalan and his group showed that CNCs $(30-300 \mathrm{mg} / \mathrm{ml}) \mathrm{did}$ not up-regulate the production of pro-inflammatory cytokines (IL-1 $\beta$ and TNF- $\alpha$ ) in human monocyte-derived macrophages after a 6-hour exposure [19].

It's obvious that besides the biocompatibility, the immunomodulatory properties of biomaterials should be examined before the clinical applications. The interaction of nanomaterials with the components of the immune system is particulary important in a view of its protective role. To this date, despite the biocompatibility of nanocellulose, almost nothing has been known about immunological properties of native (n)CNCs. Therefore, the study objective was to investigate the effect of nCNCs on cytotoxicity, proliferation and IL2 production of human peripheral blood mononuclear cells (PBMNCs) in culture.

\section{Materials and methods}

\section{nCNCs and PBMNCs}

nCNCs were produced and supplied by Betulium Ltd., Finland. The levels of concentrations used in cultivation ranged from $50 \mu \mathrm{g} / \mathrm{ml}$ to $400 \mu \mathrm{g} /$ $\mathrm{ml}$. nCNCs were prepared in complete Roswell Park Memorial Institute (RPMI)-1640 medium containing $10 \%$ fetal calf serum (FCS), $50 \mu \mathrm{M}$ 2-mercaptoethanol (all from Sigma-Aldrich), and $100 \mathrm{U} / \mathrm{ml}$ penicillin, $20 \mathrm{\mu g} / \mathrm{ml}$ gentamicin, 100 
$\mathrm{mg} / \mathrm{ml}$ streptomycin (Galenika).

The mononuclear cells were obtained from the voluntary healthy blood donors (buffy coats) at the Department of Blood Transfusion, University Hospital in Foca, upon receiving a signed informed consent in accordance with the Declaration of Helsinki. Approval for all the experiments was obtained from the Ethics Comittee of the University of East Sarajevo, Faculty of Medicine in Foca (permission date October $24^{\text {th }} 2018$, Foca). Buffy coat was diluted with $0.02 \%$ ethylenediaminetetraacetic acid disodium salt dihydrate (NaEDTA) in $0.01 \mathrm{M}$ phosphate buffered saline (PBS) in 1:2 $\mathrm{M}$ ratio and gently inflicted on the density gradient (Sigma-Aldrich). After centrifugation $\left(1000 \mathrm{xg}, 20 \mathrm{~min}, 20^{\circ} \mathrm{C}\right)$, the interphase containing PBMNCs was transferred to a new sterile conical tube. For removal of platelets, cells were centrifugated four times $(130 \mathrm{xg}, 10 \mathrm{~min}, 20$ ${ }^{\circ} \mathrm{C}$ ) with $0.02 \%$ NaEDTA in PBS. Eventually, the mononuclears were resuspended in complete medium. After Trypan blue staining ( $1 \%$ in physiological solution), their viability and number were estimated using a light microscope (Olympus).

\section{Necrosis and apoptosis}

PBMNCs (3x105/well of 96-well plates (Sarstedt)) have been plated in complete medium with $\mathrm{nC}$ NCs $(50 \mu \mathrm{g} / \mathrm{ml}-400 \mu \mathrm{g} / \mathrm{ml})$ or without nCNCs (control) in an incubator with $37^{\circ} \mathrm{C}, 5 \% \mathrm{CO}_{2}$ and $90 \%$ humidity for $48 \mathrm{~h}$. All cultures were set up in triplicates. After that, PBMNCs cultures were collected, filtrated and centrifuged (130xg, $10 \mathrm{~min})$ for the purpose of removal of remaining $\mathrm{nCNC}$ in the supernatants.

After staining the PBMNCs with propidium iodide (PI) (Sigma-Aldrich) $20 \mu \mathrm{g} / \mathrm{ml}$ in PBS, the viability was determined using flow cytometry (Sysmex Partec Cube 6). Necrotic cells were determined as PI+ cells. Minimal number of analyzed cells was 5.000 within a sample. The results are shown as percentages of necrotic cells.

PI $(50 \mu \mathrm{g} / \mathrm{ml})$ staining of mononuclears in hypotonic citric/Triton-X buffer was used for apoptosis detection. The analysis was done by cytofluorometery, as specified in necrosis assay. Hypodiploid cells (sub-G0 pick) presented apoptotic population. Minimal number of analyzed cells per sample was 5.000. The results are shown as percentage of cells in apoptosis.

\section{MTT asay}

PBMNCs were sowed in 96-well plates (Sarstedt) ( $3 \times 10^{5}$ cells per well, in triplicates), in complete medium. The cells were stimulated with phytohemagglutinin (PHA) $(20 \mu \mathrm{g} / \mathrm{ml})$. After that, 20 $\mu l$ of $n C N C$ suspension in complete RPMI medium was added, and finally concentration per well was $50 \mu \mathrm{g} / \mathrm{ml}-400 \mu \mathrm{g} / \mathrm{ml}$. Negative controls were the wells with PBMNCs cultivated in medium alone. The mononuclears had been incubated for $72 \mathrm{~h}$ at $37^{\circ} \mathrm{C}$, with $5 \% \mathrm{CO}_{2}$ and $90 \%$ humidity. The wells with nCNCs at the corresponding concentrations in complete medium served as additional controls, whereas the blank controls were those wells with medium alone. The metabolic activity of PBMNCs was detected by a colorimetric assay [20].

After $48 \mathrm{~h}$ the plates were centrifuged (900xg, 8 $\mathrm{min})$, followed by removing the supernatants. Following this, the 3-(4.5-dimethylthiazol-2-yl)-2.5-diphenyltetrazolium bromide (MTT, final concentration $500 \mu \mathrm{g} / \mathrm{ml}$ ) (Sigma-Aldrich) solution was added to wells. After a four-hour period of incubation, 10\% sodium dodecyl sulphate (SDS) (Merck) was added to each well. The next day, optical density of the evolved colour was analyzed by ELISA reader (BioTek Instruments). The values were presented as the metabolic activity (\%) relative to the analogous negative controls used as $100 \%$.

\section{${ }^{3}[\mathrm{H}]-$ thymidine uptake assay}

PBMNCs $\left(3 \times 10^{5} /\right.$ well, in triplicates, of 96-well plates (Sarstedt)) were stimulated (PHA, $20 \mu \mathrm{g} /$ $\mathrm{ml}$ ) and cultured alone or with appropriate concentrations of nCNCs $(50 \mu \mathrm{g} / \mathrm{ml}-400 \mu \mathrm{g} / \mathrm{ml})$. After $4^{\text {th }}$ day, ${ }^{3}[\mathrm{H}]$-thymidine $(1 \mu \mathrm{Ci} /$ well $)$ (Amersham) was added for the last $8 \mathrm{~h}$. The cells were harvested at the end of the cultivation period. The radioactivity (count per minutes) was detected by scintillation counter (Beckman). The results were presented as percentages compared to the proliferation of cells without nCNC (control, 100\%). 


\section{Detection of IL-2}

The concentrations of interleukin-2 (IL-2) were determined using the supernatants of PHA-stimulated PBMNCs cultures. Appropriate kit (BioLegend) was used in enzyme-linked immunosorbent assay (ELISA) for the measurements of the concentrations expressed in $\mathrm{pg} / \mathrm{ml}$. The standard curves were used for assessing the concentrations of IL-2, according to known concentrations of this cytokine.

\section{Statistical analysis}

The results are shown as mean \pm standard deviation (SD) values of at least three independent experiments (different healthy donors). The data was analyzed using One-way ANOVA to evaluate the differences between the experimental and corresponding control samples. All statistical analysis was performed in GraphPad Prism software (La Jolla, CA, USA). Values at $\mathrm{p}<0.05$ were considered statistically significant.

\section{Results}

\section{Dose-dependent effect of nCNCs on the cytotoxicity of PBMNCs}

The first aim of this study was to investigate cytotoxicity of different concentrations of nCNCs (50-400 $\mu \mathrm{g} / \mathrm{ml})$. Cytotoxicity was assesed by testing necrosis and apoptosis of PBMNCs, as described in materials and methods.

Results presented in Fig. 1A show that nCNCs do not significantly affect the percentage of necrotic cells compared to control. However, when testing apoptosis, it can be seen (Fig. 1B) that the highest concentration of nCNCs (400 $\mu \mathrm{g} / \mathrm{ml})$ induce apoptosis of PBMNCs $(\mathrm{p}<0.05)$.

\section{Effect of nCNCs on the proliferation of PBMNCs}

The proliferation of PBMNCs, stimulated with PHA, was measured by MTT and [3H]-thymidine uptake assays. Results presented in Fig.2 show, unexpectedly, that the highest concentration of nCNCs $(400 \mu \mathrm{g} / \mathrm{ml})$ increased the metabolic activity of PBMNCs $(\mathrm{p}<0.05)$ compared to
A

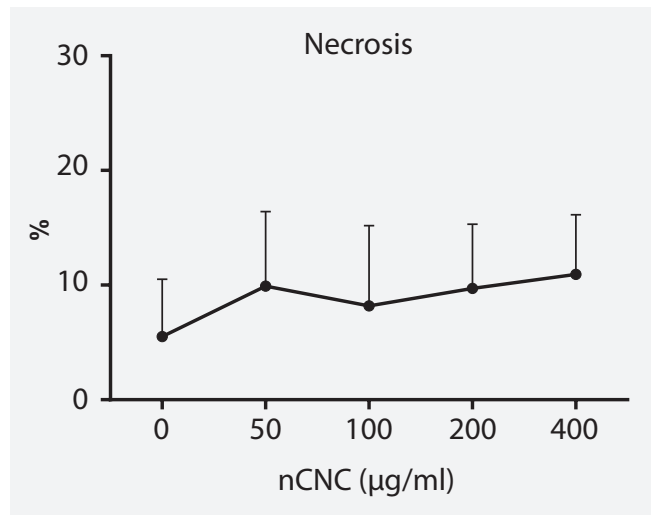

B

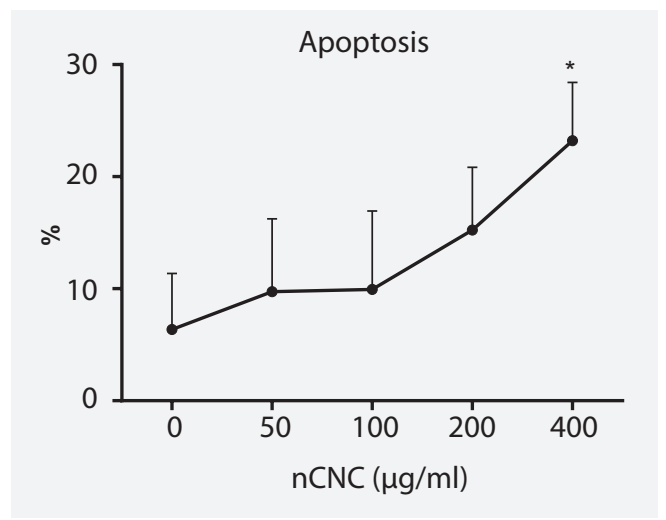

Figure 1. Effect of nCNCs on necrosis and apoptosis of PBMNCs, ${ }^{*} \mathrm{p}<0.05$; ${ }^{* *} \mathrm{p}<0.001$ compared to control $(\mathrm{n}=3)$

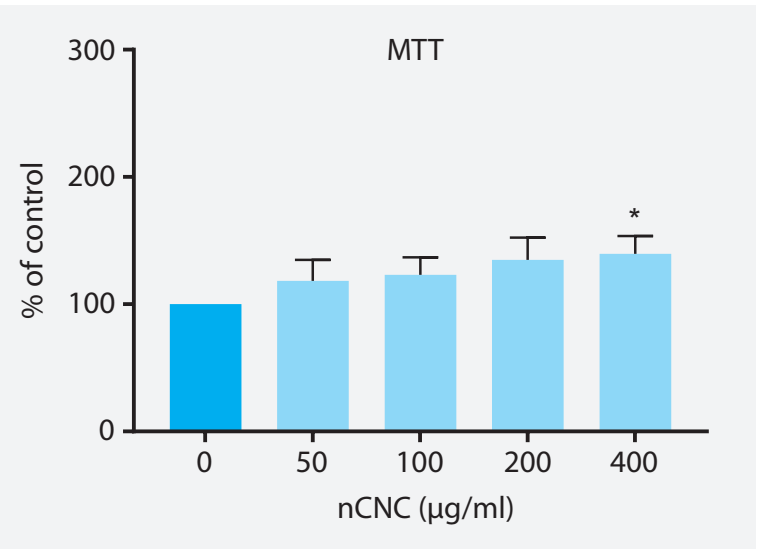

Figure 2. Effect of nCNCs on the metabolic activity of PBMNCs, ${ }^{*} \mathrm{p}<0.05 ;{ }^{* *} \mathrm{p}<0.001$ compared to control $(\mathrm{n}=3)$

control. Other concentrations have no significant modulating effect. Opposite to this, there are the results presented in Fig. 3 where significant induction of proliferation was confirmed for lower concentrations of nCNCs $(50 \mu \mathrm{g} / \mathrm{ml}$ and $100 \mu \mathrm{g}$ / $\mathrm{ml})(\mathrm{p}<0.05$ and $\mathrm{p}<0.001$, respectively). 


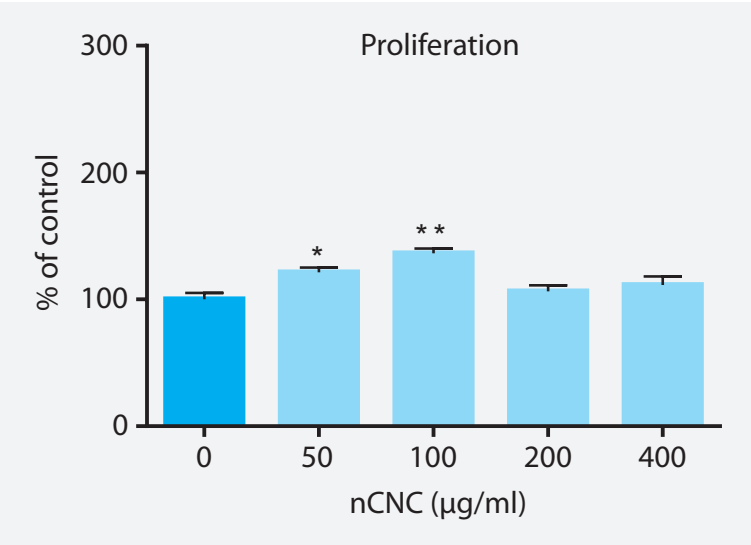

Figure 3. Effect of nCNCs on the proliferation of PBMNCs in culture, ${ }^{*} p<0.05 ;{ }^{* *} p<0.001$ compared to control $(\mathrm{n}=3)$

The production of IL-2 was determined analysing supernatants of the mononuclear cultures stimulated with PHA. The PBMNCs cultivated with lower concentration of nCNCs $(100 \mu \mathrm{g} / \mathrm{ml})$ produced significant higher level of IL-2 compared to the control cells $(\mathrm{p}<0.001)$, whereas other concentrations $(200 \mu \mathrm{g} / \mathrm{ml}$ and $400 \mu \mathrm{g} / \mathrm{ml})$ were non-modulatory (Fig. 4). These results correlate with increased proliferation of PBMNCs.

\section{Discussion}

Nanocellulose has become a promising substrate as medical implants [21,22], cardiovascular applications [23], tissue engineering [24], wound-healing [25], drug excipient and delivery [26], as well as a promising substrate used for antimicrobial purposes [27]. In addition to the typical applications, it has been attempted for nanocell $u$ lose to be used some new biomedical areas such as capture of DNA oligomers [28], cancer targeting [29], biology-device interfaces [30] and biological detection [31].

Compared to other nanocellulose materials, nCNCs possess attractive features including surface chemistry, ability to interact with another polymeric materials, mechanical advantages and comparative affordability and sustainability [3234]. However, prior to clinical application, it is important to define their biocompatibility and interactions with the context of the constituents of the immune system.

In the study, we investigated the effect of

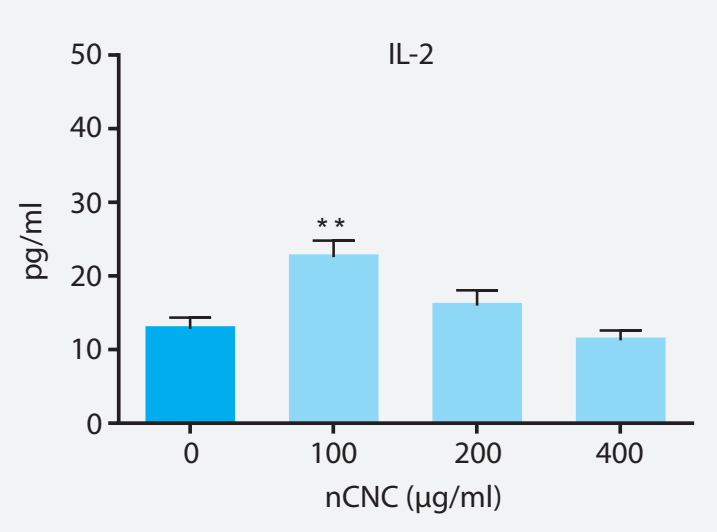

Figure 4. Effect of nCNCs on the IL-2 production in PBMNCs cultures, ${ }^{*} \mathrm{p}<0.05 ;{ }^{* *} \mathrm{p}<0.001$ compared to control $(\mathrm{n}=3)$

nCNCs on cytotoxicity and their capability to modulate proliferation of $\mathrm{T}$ cells using human PHA-activated PBMNCs as in vitro model. Our cytotoxicity research demonstrated that $\mathrm{nCNCs}$ were not apoptosis at the highest concentration $(400 \mu \mathrm{g} / \mathrm{ml})$ were concerned. In contrast, a significant stimulating effect on PBMNCs was observed when using lower concentrations. This is the first report on the topic.

Pereira et al. demonstrated that cotton CNCs (above $200 \mu \mathrm{g} / \mathrm{ml}$ ) may induce cell death of mammalian fibroblasts in vitro [35]. This phenomenon was confirmed by flow cytometry analysis and increased expressions of cell stress biomarkers (heat shock protein 70.1 and peroxiredoxin1) and apoptosis-associated molecular markers such as BCL-2 associated X protein and B-cell leukemia (BCL). In line with these outcomes, a dose-dependent cytotoxicity of cotton CNCs was observed using an in vitro model of the human epithelial airway barrier [16]. In this 3D triple cell coculture model, epithelial cells had been exposed to the multiwalled carbon nanotubes (MWCNTs), cotton CNCs and crocidolite asbestos fibers (CAFs) for $24 \mathrm{~h}$, within the same levels of concentrations ranging between 0.005 and $0.03 \mathrm{mg} / \mathrm{ml}$. It was demonstrated that cotton CNCs induced cytotoxicity but in a lower degree compared to the two other types of nanomaterials. Yanamala and co-workers showed toxicity of CNCs after pulmonary exposure of C57BL/ 6 mice to two differently processed forms of $\mathrm{CNCs}$ [15]. It is of interest that $\mathrm{CNCP}$ (powder form) el- 
evated biomarkers of tissue damage to a higher extent, whereas greater increases in inflammatory mediators and oxidative stress markers were detected in mice exposed to CNC suspension (10 wt \%; gel/suspension).

However, some opposite results were published. For example, no cytotoxic effects of CNCs was confirmed against nine different cell lines (bEnd.3, HBMEC, 7MCF-10A, RAW 264., MDAMB-468, MDA-MB-231, PC-3, KB and C6) in the concentration range $0-50 \mu \mathrm{g} / \mathrm{mL}$, aftert $48 \mathrm{~h}$ [17]. Also, 24-hour exposure to the aerosolised CNCs ( 0.14 to $\left.1.57 \mu \mathrm{g} / \mathrm{cm}^{2}\right)$ did not decrease the viability of cells in the 3D multi-cellular model of the human epithelial airway barrier [18]. In vitro and in vivo cytotoxicity tests with bacterial cellulose (BC), under the conditions and concentrations used, shown no evidence of toxic effect [36, 37]. CNF did not induce necrosis, apoptosis or any DNA damage in different cell lines, unlike chemically modified CNFs $[5,6,38]$. Overall, it seems that many of the observed differences can be ascribed to the wide variety of factors. The significance of appropriate biological systems (cell type), material origin, treatment and characterization, as well as cell exposure doses and time, is particularly accentuated by the seemingly directly opposing results of previous investigations. It seem that, in further studies, clear understanding of these factors is of the utmost importance and is inevitable for testing toxicological behavior of nCNCs and nanocellulose in general. However, the general conclusion is that $\mathrm{CNCs}$, at the similar concentrations used by other authors, are not cytotoxic for human PBMNCs.

In contrast to the cytotoxicity study (apoptosis and necrosis), results obtained by MTT in our experiments, were different. Namely, MTT showed a significant stimulatory effect of cellular proliferation by using the highest concentration of nCNCs $(400 \mu \mathrm{g} / \mathrm{ml})$, as judged by increased optical density in the assay of the PHA-stimulated PBMNCs. This phenomenon could be explained by the interference of nCNCs with the solution of MTT, taking into consideration different findings which were obtained by using the ${ }^{3}[\mathrm{H}]$-thymidine uptake method.

The most important part of our research referred to the influence of nCNCs on prolifera- tion of T-cells in a PHA-activated model of PBMNCs. In the presence of dendritic cells (DCs) and monocytes, PHA as a T-cell mitogen induces their proliferation. PHA allows transcription of crucial elements for T-cell growth due to interaction with diverse activating molecules on these and antigen-presenting cells (APCs) and T-cell receptor $[39,40]$. In this paper, we showed, for the first time, that native $\mathrm{CNCs}$ were able to induce T-cell proliferation at lower concentrations (50 and $100 \mu \mathrm{g} / \mathrm{ml})$. The effect was observed when ${ }^{3}[\mathrm{H}]$-thymidine uptake assay was applied. It is obvious that the stimulatory effect of nCNCs is an immunological phenomenon depended on a significant increase in IL-2 level. This cytokine, as a crucial T-cell growth factor, is produced by activated T cells. Furthermore, IL-2 has a key role in promoting $\mathrm{T}$-cell activation and proliferation of only those cells that have been stimulated by cognate antigenic interaction [41].

Our findings are not in accordance with the results demonstrated by Moreira et al. who revealed that $B C(100 \mu \mathrm{g} / \mathrm{ml}-1 \mathrm{mg} / \mathrm{ml})$ inhibited the proliferation of $\mathrm{CHO}$ cells and $3 \mathrm{~T} 3$ fibroblasts after $72 \mathrm{~h}$ of cultivation [42]. In line with this is slight inhibition of cellular proliferation confirmed on bacterial nanocellulose membranes [43]. Čolić and colleagues confirmed that CNFs $(250 \mu \mathrm{g} /$ $\mathrm{ml}-1 \mathrm{mg} / \mathrm{ml}$ ) slightly decreased the proliferation of PHA-stimulated PBMNCs, accompanied by down-regulation of IL-2 [8]. Such properties of $\mathrm{CNFs}$ were the result of induction of tolerogenic human DCs, which were able to down-regulate Th1 and Th17 cells, and up-regulate Th2 and Treg [9]. On the other hand, the nanocomposite consisting of CNFs, initially showed inhibitory effect on the proliferation of endothelial and human ligament cells, while exerting a stimulatory effect afterwards [44].

According to the previous results, we suppose that APCs, particularly DCs, predominantly mediate the nCNCs up-regulating effect on activation of T-cells. In this sense, it is worth mentioning that DCs, as first components of the immune system recognizing nanomaterials, have a crucial function in initiating and modulating primary $\mathrm{T}$-cell responses. What is more interesting, these interaction can lead to the initiation of either an immunogenic (inflammatory) or a tolerogenic 
(anti-inflammatory) immune responses. It depends on the structural, chemical and biological properties of natural nanoscaled materials, but many other factors may affect this process such as cell types, study models, applied concentrations and exposure time [34, 45-47].

Funding source. The authors received no specific funding for this work.

Ethical approval. The Ethics Committee of the Faculty of Medicine in Foca approved the study and informedconsent was obtained from all individual respondents.

\section{References}

1. Jorfi M, Foster EJ. Recent advances in nanocellulose for biomedical applications. J Appl Polym Sci 2015;132: 41719 .

2. Kargarzadeh H, Mariano M, Gopakumar D, Ahmad I, Thomas S, Dufresne A, et al. Advances in cellulose nanomaterials. Cellulose 2018;25(4):2151-89.

3. Lin N, Dufresne A. Nanocellulose in biomedicine: Current status and future prospect. European Polymer Journal. 2014;59:302-25.

4. Mondal S. Preparation, properties and applications of nanocellulosic materials. Carbohydr polym 2017;163:301-16.

5. Vartiainen J, Pöhler T, Sirola K, Pylkkänen L, Alenius $\mathrm{H}$, Hokkinen $\mathrm{J}$, et al. Health and environmental safety aspects of friction grinding and spray drying of microfibrillated cellulose. Cellulose 2011;18(3):775-86.

6. Alexandrescu L, Syverud K, Gatti A, Chinga-Carrasco G. Cytotoxicity tests of cellulose nanofibril-based structures. Cellulose 2013;20(4):1765-75.

7. Lopes VR, Sanchez-Martinez C, Strømme M, Ferraz N In vitro biological responses to nanofibrillated cellulose by human dermal, lung and immune cells: surface chemistry aspect. Part Fibre Toxicol 2017;14(1):1.

8. Čolić M, Mihajlović D, Mathew A, Naseri N, Kokol V. Cytocompatibility and immunomodulatory properties of wood based nanofibrillated cellulose. Cellulose 2015;22(1):763-78.

9. Tomić S, Kokol V, Mihajlović D, Mirčić A, Čolić M. Native cellulose nanofibrills induce immune tolerance in vitro by acting on dendritic cells. Scientific reports 2016;6:31618.

10. Tomić S, Ilić N, Kokol V, Gruden-Movsesijan A, Mihajlović $\mathrm{D}$, Bekić $\mathrm{M}$, et al. Functionalization-dependent effects of cellulose nanofibrils on tolerogenic mechanisms of human dendritic cells. Int J Nanomedicine 2018;13:6941-60.

\section{Conclusion}

For the first time, we have showed that nCNCs, at non cytotoxic concetrations $(50-100 \mu \mathrm{g} / \mathrm{ml})$, stimulate the proliferative activity of human PBMNCs, which is followed by increased production of IL-2. Further studies are needed for better exploration of the significance of this phenomenon.

The research was conducted according to the Declaration of Helsinki.

Conflicts of interest. The authors declare no conflict of interest.

11. Tashiro K, Kobayashi M. Theoretical evaluation of three-dimensional elastic constants of native and regenerated celluloses: role of hydrogen bonds. Polymer 1991;32(8):1516-26.

12. Sinko R, Qin X, Keten S. Interfacial mechanics of cellulose nanocrystals. MRS Bulletin 2015;40(4):340-8.

13. Miyamoto $\mathrm{T}$, Takahashi Si, Ito H, Inagaki H, Noishiki Y. Tissue biocompatibility of cellulose and its derivatives. J Biomed Mater Res 1989;23(1):125-33.

14. Izeboud E. Biocompatibility of cellulose and cellulose derivates. Papier (Germany). 1992.

15. Yanamala N, Farcas MT, Hatfield MK, Kisin ER, Kagan VE, Geraci CL, et al. In vivo evaluation of the pulmonary toxicity of cellulose nanocrystals: a renewable and sustainable nanomaterial of the future. ACS Wustain Chem Eng 2014;2(7):1691-8.

16. Clift MJ, Foster EJ, Vanhecke D, Studer D, Wick P, Gehr P, et al. Investigating the interaction of cellulose nanofibers derived from cotton with a sophisticated 3D human lung cell coculture. Biomacromolecules2011;12(10):3666-73.

17. Dong S, Hirani AA, Colacino KR, Lee YW, Roman M. Cytotoxicity and cellular uptake of cellulose nanocrystals. Nano Life 2012;2(03):1241006.

18. Endes C, Schmid O, Kinnear C, Mueller S, Camarero-Espinosa $S$, Vanhecke D, et al. An in vitro testing strategy towards mimicking the inhalation of high aspect ratio nanoparticles. Part Fibre Toxicol 2014;11(1):40.

19. Catalán J, Ilves M, Järventaus H, Hannukainen KS, Kontturi E, Vanhala E, et al. Genotoxic and immunotoxic effects of cellulose nanocrystals in vitro. Environ Mol Mutag 2015;56(2):171-82.

20. Tada H, Shiho O, Kuroshima K-i, Koyama M, Tsukamoto K. An improved colorimetric assay for interleukin 2. J Immunol Methods 1986;93(2):157-65. 
21. Hagiwara Y, Putra A, Kakugo A, Furukawa H, Gong JP. Ligament-like tough double-network hydrogel based on bacterial cellulose. Cellulose. 2010;17(1):93-101.

22. Eyholzer C, Borges de Couraça A, Duc F, Bourban $\mathrm{P}$, Tingaut $\mathrm{P}$, Zimmermann $\mathrm{T}$, et al. Biocomposite hydrogels with carboxymethylated, nanofibrillated cellulose powder for replacement of the nucleus pulposus. Biomacromolecules 2011;12(5):1419-27.

23. Brown EE, Hu D, Abu Lail N, Zhang X. Potential of nanocrystalline cellulose-fibrin nanocomposites for artificial vascular graft applications. Biomacromolecules 2013;14(4):1063-71.

24. Wen X, Zheng Y, Wu J, Wang L-N, Yuan Z, Peng $\mathrm{J}$, et al. Immobilization of collagen peptide on dialdehyde bacterial cellulose nanofibers via covalent bonds for tissue engineering and regeneration. International Journal of Nanomedicine 2015;10:4623.

25. Gonzalez JS, Ludueña LN, Ponce A, Alvarez VA. Poly (vinyl alcohol)/cellulose nanowhiskers nanocomposite hydrogels for potential wound dressings. Mater Sci Eng C Mater Biol Appl 2014;34:54-61.

26. Janjic M, Pappa F, Karagkiozaki V, Gitas C, Ktenidis $\mathrm{K}$, Logothetidis S. Surface modification of endovascular stents with rosuvastatin and heparin-loaded biodegradable nanofibers by electrospinning. International Journal of Nanomedicine 2017;12:6343.

27. Liu K, Lin X, Chen L, Huang L, Cao S. Dual-functional chitosan-methylisothiazolinone/microfibrillated cellulose biocomposites for enhancing antibacterial and mechanical properties of agar films. Cellulose 2014;21(1):519-28.

28. Tabuchi M, Baba Y. Design for DNA separation medium using bacterial cellulose fibrils. Anal Chem 2005;77(21):7090-3.

29. Dong S, Cho HJ, Lee YW, Roman M. Synthesis and cellular uptake of folic acid-conjugated cellulose nanocrystals for cancer targeting. Biomacromolecules 2014;15(5):1560-7.

30. Shi Z, Li Y, Chen X, Han H, Yang G. Double network bacterial cellulose hydrogel to build a biology-device interface. Nanoscale 2014;6(2):970-7.

31. Qin G, Panilaitis BJ, Kaplan ZSDL. A cellulosic responsive "living" membrane. Carbohydrate polymers 2014;100:40-5.

32. Habibi Y, Lucia LA, Rojas OJ. Cellulose nanocrystals: chemistry, self-assembly, and applications. Chem Rev 2010;110(6):3479-500.

33. Sacui I, Nieuwendaal RC, Burnett DJ, Stranick SJ, Jorfi M, Weder C, et al. Comparison of the properties of cellulose nanocrystals and cellulose nanofibrils isolated from bacteria, tunicate, and wood processed using acid, enzymatic, mechanical, and oxidative methods. ACS Appl Mater Interfaces. 2014;6:6127-38.
34. Dobrovolskaia MA, McNeil SE. Immunological properties of engineered nanomaterials. Nat Nanotechnol 2007;2(8):469.

35. Pereira MM, Raposo N, Brayner R, Teixeira E, Oliveira V, Quintão CCR, et al. Cytotoxicity and expression of genes involved in the cellular stress response and apoptosis in mammalian fibroblast exposed to cotton cellulose nanofibers. Nanotechnology 2013;24(7):075103.

36. Jeong SI, Lee SE, Yang H, Jin Y-H, Park C-S, Park YS. Toxicologic evaluation of bacterial synthesized cellulose in endothelial cells and animals. Molecular and Cellular Toxicology 2010;6(4):370-7.

37. Kim G-D, Yang H, Park HR, Park C-S, Park YS, Lee SE. Evaluation of immunoreactivity of in vitro and in vivo models against bacterial synthesized cellulose to be used as a prosthetic biomaterial. BioChip 2013;7(3):201-9.

38. Hua K, Carlsson DO, Ålander E, Lindström T, Strømme M, Mihranyan A, et al. Translational study between structure and biological response of nanocellulose from wood and green algae. RSC Advances 2014;4(6):2892-903.

39. O’Flynn K, Krensky AM, Beverley PC, Burakoff SJ, Linch DC. Phytohaemagglutinin activation of T cells through the sheep red blood cell receptor. Nature. 1985;313(6004):686.

40. Mihajlovic D, Vucevic D, Chinou I, Colic M. Royal jelly fatty acids modulate proliferation and cytokine production by human peripheral blood mononuclear cells. European Food Research and Technology. 2014;238(5):881-7.

41. Bachmann MF, Oxenius A. Interleukin 2: from immunostimulation to immunoregulation and back again. EMBO Reports 2007;8(12):1142-8.

42. Moreira S, Silva NB, Almeida-Lima J, Rocha HAO, Medeiros SRB, Alves Jr C, et al. BC nanofibres: in vitro study of genotoxicity and cell proliferation. Toxicology Letters 2009;189(3):235-41.

43. Bäckdahl H, Helenius G, Bodin A, Nannmark U, Johansson BR, Risberg B, et al. Mechanical properties of bacterial cellulose and interactions with smooth muscle cells. Biomaterials 2006;27(9):2141-9.

44. Mathew AP, Oksman K, Pierron D, Harmand MF. Biocompatible fibrous networks of cellulose nanofibres and collagen crosslinked using genipin: potential as artificial ligament/tendons. Macromolecular Bioscience 2013;13(3):289-98.

45. Aldinucci A, Turco A, Biagioli T, Toma FM, Bani D, Guasti D, et al. Carbon nanotube scaffolds instruct human dendritic cells: modulating immune responses by contacts at the nanoscale. Nano letters 2013;13(12):6098-105. 
46. Tomić S, Đokić J, Vasilijić S, Ogrinc N, Rudolf R, Pelicon $\mathrm{P}$, et al. Size-dependent effects of gold nanoparticles uptake on maturation and antitumor functions of human dendritic cells in vitro. PloS One. 2014;9(5):e96584.
47. Čolić M, Džopalić T, Tomić S, Rajković J, Rudolf $\mathrm{R}$, Vuković G, et al. Immunomodulatory effects of carbon nanotubes functionalized with a Toll-like receptor 7 agonist on human dendritic cells. Carbon 2014;67:273-87.

\title{
Celulozni nanokristali indukuju dozno-zavisni efekat na citotoksičnost i proliferaciju humanih mononuklearnih ćelija periferne krvi
}

\author{
Miloš Vasiljevićn , Sergej Tomić², Marina Bekić², Bojan Joksimović1, \\ Dragana Vučević ${ }^{3}$, Miodrag Čolić1,2
}

'Univerzitet u Istočnom Sarajevu, Medicinski fakultet Foča, Centar za Biomedicinska istraživanja, Foča, Republika Srpska, Bosna i Hercegovina

2Univerzitet u Beogradu, Institut za primenu nuklearne energije, Beograd, Srbija

${ }^{3}$ Vojno-medicinska akademija, Institut za medicinska istraživanja, Beograd, Srbija

Uvod. Celulozni nanokristali (CNCs) su atraktivni prirodni materijali koji imaju brojne primjene u oblasti biomedicine. Zahvaljujući specifičnim biomehaničkim svojstvima, hemijskim karakteristikama njihove površine, niskoj cijeni i obnovljivosti izvora, pripadaju naprednim nanomaterijalima i predstavljaju odličnu zamjenu za tradicionalne celulozne materijale. Međutim, prije biomedicinske primjene neophodno je provjeriti citokompatibilnost i imunomodulacijska svojstva prirodnih (n)CNCs, koja nisu u potpunosti istražena. Zato je cilj ovog rada bio da se ispita dozno zavisni efekat nCNCs na citotoksičnost i proliferaciju humanih mononuklearnih ćelija periferne krvi (PBMNCs) in vitro.

Metode. PBMNCs, dobijene od zdravih dobrovoljnih davaoca krvi, su kultivisane sa nCNCs. Vijabilnost ćelija je analizirana pomoću protočne citometrije, dok je proliferacija ispitivana na osnovu MTT testa, testa ugradnje [3H]-timidina i detekcijom produkcije interleukina-2 (IL-2).

Rezultati. Rezultati citotoksičnosti pokazuju da nijedna od koncentracija nCNCs (50-400 $\mu \mathrm{g} / \mathrm{ml}$ ) nije uticala na nekrozu PBMNCs, dok je apoptozu indukovala najveća koncentracija nCNCs u poređenju sa kontrolom $(p<0,05)$. Neočekivano, najveća koncentracija nCNCs je povećala metaboličku aktivnost fitohemalutininom (PHA)-stimulisanih ćelija u poređenju sa kontrolom $(p<0,05)$. Suprotno ovim rezultatima, manje koncentracije nCNCs $(50$ $\mu \mathrm{g} / \mathrm{ml}$ and $100 \mu \mathrm{g} / \mathrm{ml}$ ) su stimulisale proliferaciju PBMNCs ( $<<0,05 \mathrm{i} \mathrm{p}<0,001$ ). To je bilo praćeno povećanjem produkcije IL-2 $(100 \mu \mathrm{g} / \mathrm{ml})(\mathrm{p}<0,001)$.

Zaključak. Rezultati ukazuju da necitotoksične koncentracije nCNCs moduliraju proliferaciju PBMNCs, fenomen koji do sada nije objavljen u literaturi i zato može biti koristan za dalja istraživanja.

Ključne riječi: celulozni nanokristali, mononuklearne ćelije periferne krvi, kultura, citotoksičnost, proliferacija 